\title{
Study of the current incentive rules and mechanisms to promote biofuel use in the EU and their possible application to the civil aviation sector
}

\author{
Hazariah M. Noh ${ }^{\mathrm{a}}$, Arturo Benito ${ }^{\mathrm{b}}$, Gustavo Alonso ${ }^{\mathrm{b}}{ }^{\mathrm{w}}$ \\ ${ }^{a}$ Universiti Kuala Lumpur - Malaysian Institute Aviation, Malaysia \\ ${ }^{b}$ ETSI Aeronáutica y del Espacio, Universidad Politécnica de Madrid, E-28040 Madrid, Spain
}

\begin{abstract}
A B S T R A C T
This paper deals with the need of introducing biofuels for the use of the civil aviation sector, and the different possibilities of application of incentive mechanisms if the existing market conditions do not allow their direct commercialisation. After an introduction on the main features of the civil aviation impact on climate change, a historical review of the European Union regulations to promote the energy extraction from biological resources is presented. The different incentive policies around the world are revised and compared and some indications are offered on the most recommendable procedures that might be carried out in the near future.
\end{abstract}

\section{Introduction}

Air transport is one of the most rapidly grown transport sectors. Forecasts give future air traffic yearly growth rates of $4 \%$ (EUROCONTROL, 2015; IATA, 2012). Despite of the benefits from that growth, there are concerns about the increase in aviation greenhouse gas emissions. $\mathrm{CO}_{2}$ is considered the most important greenhouse gas emitted by aircraft, being aviation responsible for about $3 \%$ of global fossil fuel consumption and $12 \%$ of transportation-related $\mathrm{C}_{2}$ emissions (Simone et al., 2013). Recent studies suggest that if the global economic growth continúes, aviation $\mathrm{CO}_{2}$ emissions are likely to experience a greater than three-fold increase between 2000 and 2050 (Alonso et al., 2014). Some industries, like long-haul tourism, depending strongly on air transport are especially concerned about the effect of this environmental impact on their future development (Vorster et al., 2012).

In response to concerns over the global environmental impacts of aviation, stakeholders nave committed to strategies of mitigation related to efficiency improvement (fleet replacement, use of larger aircraft, increased density seating inside aircraft, improvements in Air Traffic Control and navigation procedures). The calculation of the practical consequences of all those elements is rather complicated, but according to IATA the results show an average improvement in efficiency, measured in ton of fuel per RTK, around 1.9\% yearly (IATA, 2013) for the IATA members, although other studies indícate lower figures (Peeters, 2013). The ICAO Council, in its climate change mitigation program, set an aspirational target for the World Air Transport sector of $2.0 \%$ yearly improvement until 2020. Fuel efficiency is not only important from an 
environmental point of view: the aviation industry outlook on future traffic does not look realistic in the light of future crude oil production, taken that the aviation fuel percentage of refinery output cannot be increased hugely (Nygren et al., 2009).

Sustainable, advanced-generation aviation biofuels will play a large role in reducing $\mathrm{CO}_{2}$ emissions (Krammer et al., 2013). The European ETS Directive (EC, 2008) considers a zero emission factor for aviation biofuels, although assessments of life-cycle $\mathrm{CO}_{2}$ emissions typically show a reduction potential compared to fossil jet fuel in the order of 30-90\%, depending on feedstock and production processes (Stratton et al., 2010; Vera-Morales and Schafer, 2009).

On the biofuel usage in aviation, most of the specification and operational questions have been already answered and no technological show-stopper is seen. However, the economic viability is still far from being made secure (Halog and Manik, 2011; Sims et al., 2011; De Gorter and Just, 2010; Demirbas, 2009).

Data suggest that the proportion of biofuels in total fuel consumption by commercial aviation was $0.5 \%$ in 2009 and will rise to $15.5 \%$ in 2024 in a "moderate" scenario, and to 30.5\% in an "ambitious" scenario (Sgouridis et al., 2011). In the European Union, the European Commission have launched the "European Advanced Biofuels Flightpath", an industrywide initiative to speed up the market uptake of aviation biofuels in Europe. It provides a roadmap to achieve an annual production of two million tonnes of sustainably produced biofuel for aviation by 2020 (EC, 2011). This target was one of the goals of ITAKA program and, after realizing the huge difficulties existing, it was delayed to year 2030 .

The work presented in this paper provides a review analysis on the background and current incentive rules and mechanisms to promote biofuel use in different parts of the world and particularly in the European Union, with especial attention to the applications to the air transport industry. First, a description of the initiatives to mitigate the contribution of aviation to climate change is given, highlighting the role of biofuels in that aim. Then, the different directives released during the last fifteen years by the European Union to regulate the use of biofuels are presented, followed by an analysis of the development of biofuels in aviation and the problems being faced. The following section provides a review of incentive policies being applied in different parts of the world, particularly in the United States and in the European Union. Finally, a discussion on the effectiveness of those policies is presented.

\section{Aviation and climate change: the role of biofuels}

In chronological terms, the international work on a regulatory limitation of the greenhouse gas emissions from civil aviation started in December 1997, when the third meeting of the Conferences of the Parties (COP/3), held in Kyoto, failed to allocate international aviation emissions to specific countries and decided to tackle this task from a global perspective with the help of the International Civil Aviation Organization (ICAO), who will take care of the analysis of the problem and look for the most adequate instruments to solve it (Benito, 2012).

Under the patronage of ICAO, the International Panel on Climate Change performed an exhaustive study titled Aviation and the global atmosphere (IPCC, 1999), published in 1999, covering all the civil aviation impacts on the atmospheric environment. Main conclusions of the analysis quantified the civil aviation effect on atmospheric warming in $3 \%$ of all the man-made activities impact (anthropogenic contribution). As the growth rate of civil aviation is high, in absence of specific actions, that participation may go up to $5 \%$ in 2050 , according to the most likely scenarios contemplated in this study.

The main reason of this increase was due to the historical fact of airtransport growth rate being higher than the efficiency improvements of this transport mode, including the three basic elements: vehicles, operation and infrastructures. While historical global consumption figures are difficult to link with transportation volumes, some recent research (Azzam et al., 2010) shows efficiency gains, measured as fuel consumption per Revenue tonne-kilometre (RTK), of 1.5-2.0\% per year. As the number of RTKs has been increasing at $4.5-5.0 \%$, the net result offers an increase of $3 \%$ in yearly $\mathrm{C}_{2}$ emissions, if standard kerosene continues to be the only used fuel.

Looking for a solution that permits the reduction of climate change contribution without taking drastic measures of demand reduction, ICAO adopted the so called Four Pillar policy (IATA, 2009; Benito, 2007), recommending to the Member States the adoption of four groups of actions:

(a) New technology developments

The aeronautical industry is one of the highest R\&D investment sectors but, as all the technologically leading sectors, project maturation periods are long and basic technology research cost are extremely high. The economic life of the products is, by consequence, very long Qiang, 2013).

The irruption of climatic change as a priority target in the development of new prototypes has put additional pressure in the programs to reduce fuel consumption, already very important for market competitiveness reasons. ICAO is collaborating in this effort by introducing a new requirement of $\mathrm{CO}_{2}$ emissions certification for new civil aircraft models. The applicable procedures were approved by ICAO 38 General Assembly in October 2013 (ICAO, 2013a) and the values not to be exceeded will be included in the Annex 16 to the Chicago Convention by 2016, with the aim of a year 2020 application.

The implications of new aviation technologies in infrastructure, i.e. airports are also important (Kivits et al., 2010). The development of biofuels, more specifically drop-in biokerosene (a type of kerosene of biological origin, the specification of which is very similar to oil-derived kerosene and can be mixed with it without any difference in its use), is being fostered through the ICAO Global Framework for Aviation Alternative Fuels (IGFAAF) and has been 
included as well in the work of ICAO Committee for Aviation Environmental Protection (CAEP), with the creation in November 2013 of a dedicated group (AFTF Alternative Fuels Task Force) to design a procedure for quantifying the net life-cycle $\mathrm{CO}_{2}$ reduction results of the different origin biofuel consumption.

(b) Infrastructure improvements

Insufficient infrastructure supply causes energetic resources waste and an increase in greenhouse gas emissions by three different ways: airport congestion induces additional holdings in the terminal area or in flight; airway congestion obliges to fly at non optimal altitudes and/or speeds, and inadequate air space structure makes flight trajectories longer than the shortest orthodromic track.

Both United States (Next Gen ATM program, FAA, 2015) and Europe (Single Sky program, EUROCONTROL, 2015) are committed to introduce advanced Air Traffic Control Systems in the next decade to obtain fuel consumption efficiency improvements in the 5-8\% order. ICAO continues to develop and update the necessary tools and guidance to assess the benefit associated with those ATM improvements and the environmental benefits associated with the implementation of the Aviation System Block Upgrades (ASBUs) strategy.

(c) Optimized operation procedures

ICAO has reviewed and updated the circular 303 Operational opportunities to minimize fuel use and reduce emissions (ICAO, 2004) to transform it in a Technical Manual, subject to continuous revision and adaptation. This publication covers the whole flight planning procedure and registers the energetic efficiency best practices applied in the different Member States, to facilitate the dissemination within the aeronautical community. A similar document referring to the airline operational practices had been published by the International Air Transport Association (IATA, 2001).

(d) Market Based Measures (MBM)

In spite of the intensification of all those technical actions it is unlikely that their effects will be enough to mitigate the civil aviation contribution to climate change. Then, some regulatory measures should be needed. During the 2001-2004 period, ICAO studied different market tools to collaborate in emissions reduction, divided in four different categories: Voluntary agreements among Administrations, operators and manufacturers, taxes on fuel or on passengers and cargo, $\mathrm{CO}_{2}$ charges and emissions trading. Each option was carefully analysed from the legal, technical and environmental point of view. The conclusion of the study, approved by the General Assembly (ICAO, 2004) showed that a worldwide open Emission Trading System (ETS) was the most efficient market based mechanism. The use of ETS, basically a cap and trade scheme, was approved by the Kyoto Protocol in 1997, allowing sectors in which improvement of energetic efficiency are very expensive, like commercial aviation, to trade emissions allowances with others that can achieve those emissions reductions at a lower cost.

Although the conclusions in favour of EIS were unanimous, no agreement was obtained for its worldwide application, because an important number of States try to defer its enter into force. In 2009 the EU, who had an ETS system working since 2003 in a number of industrial sectors, approved the inclusion of civil aviation in its ETS, starting on January 1, 2012. After a long and hectic international controversy, EU Commission accepted the application of the ETS only to the flights between two points of the EU territory, until a special group created in ICAO decide the best procedure for expanding this or a similar emissions offsetting scheme to the rest of the countries. The final ICAO decision is expected by the September 2016 General Assembly.

The 32nd ICAO General Assembly, held in September-October 2013, approved the Resolution A38-18 (ICAO, 2013b) outlining its general policy with respect civil aviation and climate change, setting quantified targets and recommending the needed procedures to achieve those goals. The airlines industry represented by IATA (2013), supports this resolution.

In terms of fuel efficiency, the Assembly resolves that States and relevant organizations will work through ICAO to achieve a global annual average fuel efficiency improvement of $2 \%$ until 2020 and an aspirational global fuel efficiency improvement rate of $2 \%$ per annum from 2021 to 2050, calculated on the basis of volume of fuel used per RTK performed. Those goals would not attribute specific obligations to individual States, and the different circumstances, respective capabilities and contribution of developing and developed States to the concentration of aviation greenhouse gas emissions in the atmosphere will determine how each State may voluntarily contribute to achieving the global aspirational goals. The States will submit their voluntary action plans outlining their respective policies and actions, and annual reporting on international aviation $\mathrm{C}_{2}$ emissions to ICAO, starting by the end of June 2015 and once every three years thereafter. This is mandatory for States, the airlines of which are carrying at least $1 \%$ of the world international RTKs, and voluntary for the rest of the States. This will be revised during the 2016 General Assembly.

A second and in no way less important target is the work of ICAO and its Member States with relevant organizations to strive to achieve a collective medium term global aspirational goal of keeping the global net carbon emissions from international aviation from 2020 at the same level, taking into account the special circumstances and the respective capabilities of States, in particular developing countries; the maturity of aviation markets; the sustainable growth of international aviation industry; and that emissions may increase due to the expected growth in international air traffic until lower emitting technologies and fuels and other mitigating measures are developed and deployed. This target of carbon neutral growth after 2020 is accepted by a number of aviation stakeholders (ATAG, 2010; IATA, 2012), and strongly depends on the utilisation of enough quantity of advanced biofuels, in addition of the participation of the other actions included in the four pillars policy. A schematic representation of the $\mathrm{C}_{2}$ emissions evolution can be seen in Fig. 1, showing clearly the important role attributed to biofuels in the task, after 2020 . 


\section{Emissions reduction roadmap}

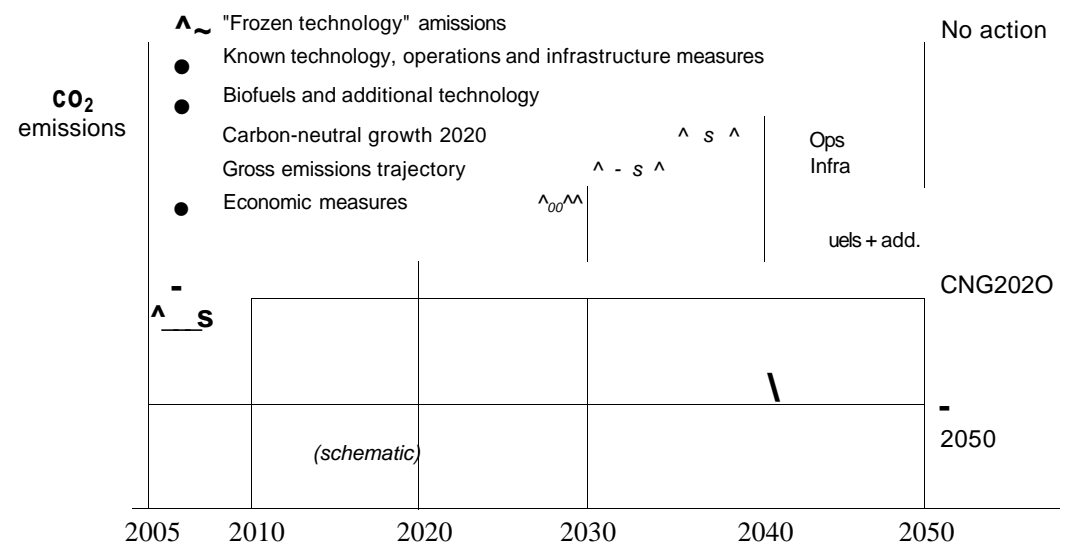

Fig. 1. Long term targets for international aviation $\mathrm{CO}_{2}$ emissions.

In this scenario, the economic measures are intended to be a temporary remedy addressed to keep the Carbon Neutral Growth (CNG) while the introduction of biofuels is large enough to curb down the total $\mathrm{CO}_{2}$ emissions. The study from Agusdinata et al. (2011) finds that at likely adoption rates biojet alone would not be sufficient to achieve the aviation emissions reduction target. In the same line Dray et al. (2012) find that the EU emissions goals will be difficult to meet, even under widespread adoption of the most promising technologies for all modes, due primarily to limitations in biofuel production capacity and a lack of technologies that would drastically reduce $\mathrm{C}_{2}$ emissions from heavy trucks and intercontinental aviation. According to Schafer and Waitz (2014), a $\mathrm{CO}_{2}$-neutral aviation sector would depend on offsetting emissions in other sectors of the economy through the use of a market-based measure. Kar et al. (2010) adds to the portfolio of measures that need to be taken (operational improvements, alternative fuels), demand reduction mechanisms. Going further, Schafer et al. (2009), even wonder if when all of these options are taken together, a more sustainable transportation system will be possible in the next thirty to fifty years, or whether we must accept a future where transportation remains a major contributor to climate change. This would not be necessary a problem, as long as other sources of emissions are reduced (Forsyth, 2011). In this sense, sustainability is a characteristic of the system as a whole, and emissions from air transport can continue growing within a system which is, overall, sustainable. It would be efficient and sustainable that air transport be part of an overall policy approach which addresses climate change, carrying a burden proportionate with the extent to which it contributes to the problem.

With respect to biofuel introduction and characteristics, ICAO asks Member States to set a coordinated approach in their national administrations in order to develop policy actions to accelerate the appropriate development, deployment and use of sustainable alternative fuels for aviation, in accordance with their national circumstances. They will also consider measures to support research and development as well as processing technology and feedstock production in order to decrease costs and support scale-up of sustainable production pathways up to commercial scale, taking into account the sustainable development of States.

Aviation biofuel should:

- Achieve important net greenhouse gas emissions reduction on a life-cycle basis, compared with a similar kerosene life-cycle.

- Respect the areas of high importance for biodiversity, conservation and benefits for people from ecosystems, in accordance with international and national regulations, converting abandoned pieces of land in productive sites.

- Contribute to local social and economic development, creating a new source of revenue, always considering that competition with food and water supply should be avoided.

In the field of economic measures, ICAO has decided to develop a global Market Based Measures (MBM) scheme for international aviation to be approved in the 2016 General Assembly. Two working groups have been formed: a high level one (EAG Environment Advisory Group) to identify the major issues and problems for Member States and make a recommendation on a global MBM scheme that appropriately addresses them, and identify key design elements, including means to take into account special circumstances and respective capabilities. The second group, GMTF (Global Market-based Measures Technical Task Force) within the CAEP structure, will evaluate the environmental and economic impact of the considered alternatives, and the mechanisms to be set up in order to control and monitor their implementation. EAG finished its work in January 2016 and was replaced by a High Level Group (HLG) in charge of reaching a consensus around a proposal to be presented to ICAO Council in June 2016 and subsequently to the General assembly in September 2016. 
The leading alternatives belong to two different families. On one side, the variants of the EIS applied by the EU, with some particular conditions to respect the wide variety of air transport conditions in developed, less developed and underdeveloped countries. The other options are global carbon offsetting schemes, a possibility supported by the airline industry and other stakeholders, which looks like the most probable option to be adopted.

The EIS option appears to be more efficient in theoretical analysis, because it provides everybody an incentive to work in emissions reduction, but its mechanism seems to be more complicated to apply, according to the brief experience with the European aviation since January 2012, and offers more difficulties for the introduction of several economic charging levels to discriminate among the States with dissimilar development levels. The offsetting seems simpler to implement but may be too close to a tax or charge to be as economically efficient as the ETS.

\section{Background EU legislation on biofuels}

During the past century there had been a number of isolated initiatives to use biological resources in order to produce energy and complement the classic energetic generation from fossil fuels, hydroelectric and nuclear facilities. However those were independent actions without any coordinated regulatory framework.

The first European Union (EU) intent to regulate and incentivize the use of biomass for energy generation was the Directive 2001/77/EC (EU, 2001a), titled on the promotion of electricity produced from renewable energy sources in the internal electricity market. It was approved on September 21, 2001 and published in the Official Journal of the European Communities (OJEC) on October 27, 2001. The Directive considered that the potential for the exploitation of renewal energy was underused in the Community, and the promotion of electricity produced from renewable energy sources was a high priority for reasons of security and diversification of energy supply, of environmental protection and of social and economic cohesion, with specific reference to biofuels in the last aspect, as indicated in the 1998 White Paper on Renewable Energy Sources.

This Directive defined renewable energy sources as non-fossil energy sources, including wind, solar, geothermal, wave, hydropower, biomass, landfill gas, sewage treatment plant gas and biogases. For the case of biomass, the definition was the biodegradable fraction of products, waste and residues from agriculture (including vegetal and animal substances), forestry and related industries, as well as the biodegradable fraction of industrial and municipal waste.

The fifteen (at that moment) Member States were given indicative targets for the year 2010, based on their renewable energy sources electricity (RES-E) production in 1997, measured in RES-E percentage of their total electricity production (Table 1).

The reference values were only indicative and the Member States were obliged to periodically report their achievements towards the target and the procedures used to progress in this field. The Directive recognized the existence of different mechanisms of support for renewable energy at the national level, including green certificates, investment aid, tax exemptions or reductions, tax refunds and direct price support schemes, but provided no indication about priorities, considering that the experience in their application was very limited. As the program will be implemented, the Commission shall present in four years' time a report with the gained experience and the proposal of a support scheme framework, taking into account five factors:

(a) Contribution to the achievement of the national indicative targets.

(b) Compatibility with the principles of the internal electricity market.

(c) Characteristics of different sources of renewable energy, together with the different technologies, and geographical differences.

(d) Promotion of the use of renewable energy sources in an effective way.

(e) Inclusion of sufficient transitional periods for national support systems of at least seven years and maintain investor confidence.

A particular aspect highlighted by the Directive was the consideration of the positive impact on regional and local development opportunities, especially as concerns small and medium-sized undertakings as well as independent power producers.

The first legislative step covering specifically the transport application of biofuels happened two years later. Directive 2003/30/EC (EU, 2003), on the promotion of the use of biofuels or other renewable fuels for transport, was approved on May 8, 2003 and published in the Official Journal of the European Union (OJEU) on May 17, 2003.

The origin of the Directive was an agreement in the European Council meeting at Gothenburg (15-16 June 2001) on a Community strategy for sustainable development consisting in a set of measures, which includes the development of biofuels. At that moment the transport sector accounted for more than $30 \%$ of final energy consumption in the Community, with a

Table 1

Renewable energy sources electricity (RES-E) production targets for $\mathbf{2 0 1 0 .}$

RES-E TW h (1997)

Total community
RES-E \% (1997)

13.9
RESE \% (2010)

22.0 
fast growing trend. The Commission White Paper European transport policy for 2010: time to decide (EU, 2001b) expected $\mathrm{C}_{2}$ emissions from transport to rise 50\% between 1990 and 2010 to around 1113 million tons per year, becoming one of the most important greenhouse gas emitters. Therefore, alternative fuels such as biofuels may play an important role in the reduction of that output.

The new Directive defined biofuels as liquid or gaseous fuel for transport produced from biomass and listed a basic, non-exclusive inventory of 10 products qualified as biofuels. In brackets, the most commonly used feedstock for the production of each one of the products:

- Bioethanol (sugarcane, corn, cellulosic).

- Biodiesel (vegetable oil, animal fat).

- Biogas (organic waste).

- Biomethanol (wood).

- Biodymethylether (agricultural methanol)).

- Bio-ETBE (ethyl-tertio-butyl-ether) (agricultural ethanol).

- Bio-MTBE (methyl-tertio-butyl-ether) (agricultural methanol.

- Synthetic biofuels (solid biomass, bio-oil and fats).

- Biohydrogen (algae, bacteria, archaea).

- Pure vegetal oil (oily seeds like Palm, soybean, rapeseed, sunflower seeds).

The focus of the Directive was the road traffic, origin of $84 \%$ of all $\mathrm{C}_{2}$ emissions from transport and, as the previous electricity Directive, was setting a non-mandatory target of $2 \%$ biofuel use by 2005 , calculated on the basis of energy content of all petrol and diesel for transport purposes, going up to $5.75 \%$ by 2010 . The introduced biofuels may be delivered as pure biofuel or at high concentration in mineral oil derivatives, in accordance with specific quality standards for transport applications, as biofuel blended in mineral oil derivatives or as liquids derived from biofuels, such as the previously listed ETBE. The Member States shall report yearly to the Commission their situation with respect to the reference target, their national targets, the objective factors limiting their national potential for production of biofuels from biomass and the national resources applied to this program.

By the end of 2006, the Commission would prepare an evaluation report, revised every two years, covering:

(a) The cost-effectiveness of the measures taken by Member States in order to promote the use of biofuels and other renewable fuels.

(b) The economic aspects and the environmental impact of further increasing the share of biofuels and other renewable fuels.

(c) The life-cycle perspective of biofuels and other renewable fuels, with a view to indicating possible measures for the future promotion of those fuels that are climate and environmentally friendly, and that have the potential of becoming competitive and cost efficient.

(d) The sustainability of crops used for the production of biofuels, particularly land use, degree of intensity of cultivation, crop rotation and use of pesticides.

(e) The assessment of the use of biofuels and other renewable fuels with respect to their differentiating effects on climate change and their impact on $\mathrm{CO}_{2}$ emissions reduction.

(f) A review of further more long-term options concerning energy efficiency measures in transport.

While the declared intention of the Directive was to reduce greenhouse gas emissions, it was made clear that any incentive program adopted by the Member States should carefully consider the agricultural, political and social implications. Promoting the use of biofuels, in keeping with sustainable farming and forestry practice laid down in the rules governing the common agricultural policy (CAP), could create new opportunities for sustainable rural development in a more market oriented CAP. Alternative fuels will only be able to achieve market penetration if they are widely available and competitive. At the same time, promotion of the production and use of biofuels could contribute to a reduction in energy import dependency.

Basic elements of support were tax allowances and blending obligations. No preference was indicated, considering that the optimum method for increasing the share of biofuels depends on the availability of resources and raw materials, on national and Community policies to promote biofuels, on tax arrangements and on the appropriate involvement of all stakeholders. It was mentioned that the blending of biofuel with fossil fuels could facilitate a potential cost reduction in the distribution system in the Community, indicating a clear preference for drop-in biofuels, mixable with current fuels and acceptable by vehicles without extensive modifications, like those required for the car use of pure ethanol, a practice spread since many years in countries like Brazil.

The revision of the results of this Directive application was not very encouraging. In 2005 the EU transport sector as a whole was using only a $1.02 \%$ of biofuel, practically half of the reference target, rising up to $2.58 \%$ in 2007 what made very difficult to reach the 5.75\% 2010 target. In 2007 only five EU countries (Austria, France, Germany, Lithuania and Sweden) went beyond $3 \%$ in their use of biofuels for transport. 
In parallel, the growth in EU biofuels consumption caused a reduction in EU self-sufficiency, as it was inducing an increase in imports far higher than the growth of the local production. Main reasons for this effect were the small quantity of available arable land and the difficulties in finding suitable areas without competing with food production.

The policies set up by this Directive were developed when the biofuel option seems not to face heavy obstacles for development and public acceptance, with the only exception of land use and consequently output availability, coming into operation from already existing branches of the agricultural industry. However, in the period 2007-2009, some problems appear, rising some doubts about the global performance of the EU policy (Ninni, 2010). These elements may be summarized in three areas:

- Indirect environmental effects of the plant cultivation for biofuel production. The production of nitrogen fertilizers, use for improve biomass crop quantities, emitted $\mathrm{N}_{2} 0$, an active greenhouse gas, and may seriously limit global warming reduction by replacing fossil fuels. An even more important effect may happen by land use change, when cultivating biofuel plants in a former forest or grass prairie, as the $\mathrm{C}_{2}$ sink properties of the former land use are lost (Gnansounou et al., 2008). The situation is worse where virgin forest is cleared since the process is both energy intensive and destroys nature's means of sequestering carbon dioxide (Marsh, 2008). This kind of repercussion, generally denominated ILUC (Indirect Land Use Change) is still a very polemic issue and there is no general agreement on the optimum way of estimate its life-cycle effect.

- Biofuel production may enter in food production competition. As a consequence, food prices will rise as a greater part of the agricultural work is devoted to produce biofuel. According to the World Bank economist Mitchell (2008), biofuel demand was responsible of $76 \%$ of the food price increase in the 2007-2008 period, although other researches emphasize the role of financial speculation in this phenomenon. The charity Oxfam holds that the subsidies provided by developed countries for biofuel crop cultivation look to poor countries like a tax on food that can tip their populations into starvation. In common with other campaigning organizations, Oxfam is pushing for an end to biofuel subsidies and further biofuel mandates (Marsh, 2008).

- Some biofuel policies may be too expensive for the national budgets of the Member States, if we take into account the scarce gains that biofuels could grant in terms of sustainability and the reduced amount of overall energy that they could provide.

In order to solve these and other weak points of the EU biofuel policy, Directive 2009/28/EC (EU, 2009) on the promotion of the use of energy from renewable sources and amending and subsequently repealing Directives 2001/77/EC and 2003/30/ EC, was approved on April, 23, 2009 and published in the OJEU on June 5, 2009.

This very extensive Directive establishes mandatory national targets for renewable energy sources (RES) share in the 2020 gross final energy consumption. It indicates that in order to reach those targets Member States may apply support schemes and measures of cooperation between different Member States and with third countries. It also makes a specific reference to the transport sector, where each Member State shall ensure that the share of energy from renewable sources in all forms of transport in 2020 is at least $10 \%$ of the final consumption of energy in transport in that Member State.

Aviation merits special consideration in the Directive, because current technological and regulatory constraints prevent the commercial use of biofuels in aviation at the time of directive approval. Then a partial exemption is provided for Member States, like Cyprus and Malta, with a great participation of aviation sector in their transport energy consumption, much larger than the 2005 EU average of $6.18 \%$. A detailed distribution of aviation $\mathrm{C}_{2}$ emissions in the different European countries and its projection into the near future can be seen in Alonso et al. (2014).

The difference between mandatory global final energy consumption targets differentiated by country and the same common target for transport energy use, is justified by the need of ensuring consistency in transport fuel specifications and availability. Because transport fuels are traded easily, Member States with low endowments of the relevant resources will easily be able to obtain biofuels from elsewhere.

Market impact of transport biofuel is taken into consideration. While it would technically be possible for the Community to meet its target for the use of energy from renewable sources in transport solely from domestic production, it is both likely and desirable that the target will in fact be met through a combination of domestic production and imports

The Directive text gives a lot of relevancy to the type of admissible support schemes. For the specific purpose of the Directive, support schemes means any instrument, scheme or mechanism applied by a Member State or a group of Member States, that promotes the use of energy from renewable sources by reducing the cost of that energy, increasing the price at which it can be sold, or increasing, by means of a renewable energy obligation or otherwise, the volume of such energy purchased. This includes, but is not restricted to, investment aid, tax exemptions or reductions, tax refunds, renewable energy obligation support schemes including those using green certificates, and direct price support schemes including feed-in tariffs and premium payments.

In any case it is desirable that energy prices reflect external costs of energy production and consumption including, as appropriate, environmental, social and healthcare costs. Any applicable support scheme shall take into account both internal and external costs.

The production of biofuels is subject to different limitations for avoiding the three disadvantages previously commented that may reduce their environmental benefits, enter in competition with food production or produce undesirable effects on the market balance. At this point, it is clearly stated that the production of biofuels should be sustainable. Biofuels used for 
compliance with the targets laid down in the Directive and those that benefit from national support schemes, should therefore be required to fulfil sustainability criteria integrated in Articles 17, 18 and 19 of the Directive. These requirements are simple for the biofuels and bioliquids produce from waste and residues, other than agricultural, aquaculture, fisheries and forestry, and more detailed for the rest, excluding biofuels produced from raw material obtained from land with high biodiversity value, primary forest, designated areas, highly bio-diverse grassland and land with high carbon stock.

Additional consideration is given to biofuel generation class, divided in first generation, when the cultivation competes with food production, second generation with no competition with food production and third generation, when no solid land is used, like in the case of algae. The last two categories are commonly referred to as advanced biofuels. While this distinction is not applied in this Directive, it will be in further legislation. The issues of social sustainability and competition with food will be the object of a report that the Commission has to provide every two years to the Parliament and the Council. Immediately after the publication of the Directive, different ecologist organizations and NGOs published a report calling for a change in the scope: the sustainability criteria in the EU law should be redefined to ensure that all environmental and social impacts are taken into account (for instance, the environmental impact of indirect land use change (ILUC)), thereby promoting only the biofuels that bring genuine overall benefits. Subsequently, the volume targets for biofuels should be replaced with a target for greenhouse gas (GHG) reduction for transport fuels (Birdlife et al., 2009).

A part of these complaints might be answered by the provisions of a new Directive 2015/15137EC (European Union, 2015) addressing the ILUC issue, giving the Member States a term up to September 10, 2017, to transpose the Directive into national legislation and up to April 6, 2017 to establish the level of their national indicative sub-targets for advanced biofuels. At this moment the movement towards advanced biofuels (not derived from food related feedstocks) appears to be very dissimilar in the EU members (Delft, 2015).

\section{Biofuels in aviation}

The development of biofuel technology for commercial aviation has made extraordinary advances in the last eight years. In February 23,2008, a Virgin Atlantic B747/400 with General Electric CF6-80C2 engines became the first commercial aircraft in making a flight with a mix of $80 \%$ conventional kerosene and $20 \%$ first generation biofuel, produced from coconut oil and seeds of babassu palm tree. Since then, more than fifteen airlines have tested the operational possibilities of different aviation biofuels with satisfactory results from the technical point of view.

Commercial aviation kerosene has a very demanding specification with tight limits for the elements contained in the fuel and strict levels of energy content, density, viscosity, flash and freeze points. From the beginning of the testing, the technical option was to produce biofuel with a high capacity of blending without changing the properties of the fluid, what in aeronautical terms is known as drop-in fuel. In this way, modification was needed neither in aircraft engine and systems nor in the logistic supply system, delivery and emergency equipment at the airports.

On July 1, 2011, the American Society for Testing and Materials (ASTM International), the most recognized body on international standards, approved a biofuel specification based on Hydro processed Esters and Fatty Acids (HEFA), with the number ASTM D7566 (ASTM, 2011). An overwhelming majority of todays in service turbine engines can operate with a mix of up to $50 \%$ of this specification biofuel in the standard kerosene.

Having been overcome the technical feasibility problems, the main hurdles are in attracting investment for biofuels production and distribution and ensuring that the industry has access to this biofuel stock, at a price that is costcompetitive with using traditional jet fuel. The industry has called on governments to assist potential biofuel suppliers to develop the necessary feedstock and refining systems - at least until the fledgling industry has achieved the necessary critical mass (ATAG, 2011a). From policymakers, the industry is looking for encouragement and the right set of legal, fiscal and policy responses to ensure this new energy stream can produce results as quickly as possible (ATAG, 2011b).

The EU accepted the challenge of promoting biofuels on air transport energy consumption. In June 2011, the European Commission, Airbus and high-level representatives of the Aviation and Biofuel producers industries launched the privatepublic program European Advanced Biofuels Flightpath (EABF) with the purpose of achieve 2 million tons of sustainable biofuels used in the EU civil aviation sector by the year 2020 (EU, 2011), now delayed to 2030. This action requires the work of every stakeholder to promote production, distribution, storage and use of sustainably produced and technically certified biofuel. For this it is necessary to join forces in establishing appropriate and effective financial mechanisms to support the construction of industrial "first of a kind" advanced biofuel production plants.

The project actions focus on the following issues:

- Facilitate the development of standards for drop-in biofuels and their certification for use in commercial aircraft.

- Work together with the full supply chain to further develop worldwide accepted sustainability certification frameworks.

- Agree on biofuel take-off arrangements over a defined period of time and at a reasonable cost.

- Promote appropriate public and private actions to ensure the market uptake of paraffinic biofuels by the aviation sector.

- Establish financing structures to facilitate the realization of $2 \mathrm{G}$ biofuel projects.

- Accelerate targeted research and innovation for advanced biofuel technologies, and especially algae.

- Take concrete actions to inform the European citizen of the benefits of replacing kerosene by certified sustainable biofuels. 
The working methods and governance will be the ones established in the Strategic Energy Technology Plan (SET-Plan) of the EU, approved on February 4, 2011. This initiative falls under the European Industrial Bioenergy Initiative (EIBI) included in SET-Plan.

EABF proposal selects three biofuel processes as main candidates for mixing with aviation kerosene:

- Synthetic Fischer-Tropsch (FT) kerosene, produced via lignocellulosic biomass gasification followed by gas cleaning and synthesis over appropriate catalysts, approved by ASTM D7566 for a 50\% blend.

- Hydrogenated Vegetable Oils (HVO), based on triglycerides and fatty acids which can originate from plats oil, algae and microbial oil. In absence of technical restraints, market forces and legislation are the main forces for oil and fat selection.

- Hydrogenated Pyrolysis Oils (HPO), based on pyrolysis oils from lignocellulosic biomass. Pyrolysis oils can be hydrotreated either in dedicated facilities or co-processed with petroleum oils in refineries.

A general discussion of the state of the art in different processes can be seen in the presentations of a Workshop held in Milan on June 18, 2012, under the title "Upstream R\&D and Innovation for biofuels in aviation" (Bauen and Maniatis, 2012a). There were presentations on Fischer-Tropsch fuel chain, alcohol to biojet fuel, pyrolysis and hydrothermal, microbial oils, HVO and algae.

The market for transport biofuel (EEA, 2013) can be split into two groups:

- First generation biofuels are commercially available, using dedicated feedstocks, such as sugar beet, oilseeds and starch crops. Sugars in these crops are fermented to produce ethanol, while oil crops provide oil that is trans-esterified to form fatty acid methyl ester. The resulting ethanol and biodiesel are then generally mixed with fossil-based liquid fuels

- Second generation biofuels are generally not yet commercially viable but are expected to play an increasing role in the coming decades. They use mainly ligno-cellulosic feed stocks, e. g. short rotation coppice, perennial grasses, forest residues and straw, but also some oil seeds not used for food, like jatropha or camelina. They can be treated by thermo-chemical or biochemical conversion. The biochemical route, being less mature, probably has a greater cost reduction potential than the thermo-chemical route, but here a wider range of synthetic fuels can be produced to better suit heavy truck, aviation and marine applications (Sims et al., 2010). Currently, there are no commercial biomass-to-liquid plants but several pre-commercial plants exist in Finland, Germany, Japan and the United States. Biochemical conversion involves pre-treatment of cellulosic biomass and enzymatically enhanced hydrolysis and subsequent fermentation to convert hemicellulose and sugar into ethanol. There are demonstration plants in the EU (Denmark, Spain and Sweden) and Canada. Other countries such as Brazil, China, Germany, Japan and the United States are also developing such second generation ethanol technologies.

Some of other promising possibilities like algal oils (third generation biofuels) or direct conversion of sugars to hydrocarbon fuels are either very high cost processes or are still in the early research phase, being unlikely of playing any significant role by 2020 . The benefits of microalgal biofuel systems include the ability to site them on marginal land ( $~ 85 \%$ of surface area of the Earth's land mass) and to utilize saline and waste water streams (Stephens et al., 2010). It seems that new technologies, e.g. tubular PBRs shall enhance the production of microalgae feedstocks for various fuel productions along with $\mathrm{CO}_{2}$ recycle for algae culture and thus reduce the pollution. More innovations are still needed for the development of technologies which reduce costs while increasing the yields. This can be realized successfully through a coherent, extensive, and well-funded R\&D program (Singh and Gu, 2010). Reports suggest that microalgal oil production could be achieved at a future target cost of US\$50/bbl (Stephens et al., 2010).

The technical certification of aviation biofuels is co-ordinated among the US based ASTM International and the UK DEF STAN organisation for Europe, producing identical specifications. FT fuels have been approved in ASTM D7566 Annex 1 and HVO fuels approval is in Annex 2, while HPO are still being tested. Similar provisions are contained in DEF STAN 91-91 Annex D. During the certification process intensive tests have been conducted both by airframe and engine manufacturers. Demonstration flights performed so far by airlines confirmed that the blend of biofuels and kerosene is "fit for purpose".

Since through the ASTM International approval process, certain types of bio kerosene and blends with conventional kerosene are recognized as meeting the conventional jet fuel ASTM 1655 specification, the existing infrastructure (most importantly pipelines, but also trucks and ships) can be used both for transport to and for fuelling at the airport. Thus the supply and logistics of certified drop-in biofuels, whatever the blend, present no problem to the distributors in this respect.

Each one of the above mentioned three processes has a different cost structure. HVO requires a modest upfront capital investment but production cost is highly dependent on vegetable oil feedstock prices, which can make up to 60-75\% of the final product price. Ligno-cellulosic FT and HPO biofuels have relatively low raw material cost, but more expensive processes, requiring high initial investments that makes a very expensive product at the beginning of the manufacturing operation. Hypothetically, the prices will get down as the scale of the production increases.

The price setting and the associated support policies need to take into account all the three main benefits of aviation biofuels (Ninni, 2010): 
(a) Reduction of external emissions of greenhouse gases in order to reduce the climate change effect of aviation.

(b) Security of supply in order to reduce and differentiate EU energy supply channels from abroad.

(c) Improvement in rural income and conditions in order to reduce existing gaps within the EU and to create new outlets for farm production.

All these benefits should be achieved complying with the sustainability criteria and without altering the balance of the EU internal market.

There is little doubt that present technology can create a fuel that replicates standard aviation kerosene from sustainable alternative raw materials, but doing so in a cost effective way and at the scale of the industry needs remains a formidable challenge. According to recent EU estimations, aviation biofuel may cost above 2000 euro per tonne, against 700 euro per tonne of fossil kerosene at 2013 prices. Obviously the European airline industry could not afford trebling the price of an element representing between $30 \%$ and $35 \%$ of its total costs without losing competitiveness to other world areas airlines.

The consequences of the oil price decrease started in the last part of 2014 are unclear and strongly dependent on the dimension and duration of this trend. As the oil share in the airline operating cost diminish, some relatively old aircraft get their useful lives prolonged and their replacement by more fuel efficient airliners is delayed. At the same time, the price gap between fossil fuel and biofuel increases, making more difficult the introduction of alternative fuels. There is no clear forecast of how long will take a future oil price recovery although most analysts believe on a lapse of four or five years before that happens. Another confusing element is the evolution of the US dollar exchange rate versus other currencies (IATA, 2015, Fig. 2). As nominal oil price is quoted in US dollars, the appreciation of USD means an increase in price for those operators receiving most of their revenues in other currencies.

This relative position may change as the oil becomes scarce and its price goes up, but some experts (Hind, 2014) suggest that feedstock prices are going up as well in not a very different way than oil, as it can be seen in Fig. 3 .

It remains the evaluation of the three external effects above mentioned. The $\mathrm{C}_{2}$ reduction may be evaluated at first sight considering the European Emissions Trading System (ETS) that gives biofuels a zero emission factor. Then biofuel consumption is practically exempted of the emissions market. Burning a tonne of kerosene emits 3.16 tonne of $\mathrm{CO}_{2}$ that, if replaced by biofuel, will not have to be compensated buying any emission allowance. Unfortunately the low price of allowances would translate this in 25 euro savings at a price of 8 euro per emitted ton. Present predictions for future $\mathrm{C}_{2}$ allowances price do not go much higher unless world States having ratified the International Framework Convention on Climate Change (IFCCC) agree on more strict rules in the future Conference of the Parties (COP) yearly meetings. Aviation's climate impacts, however, extend beyond those of $\mathrm{CO}_{2}$ alone and the impact of other climate forcing agents needs to be addressed (Dessens et al., 2014). The key is to ensure that a scientifically rigorous methodology is applied appropriate for the respective emissions effect on climate. As emissions released during flight are unlikely to change significantly when drop-in biofuels are substituted for Jet A, non- $\mathrm{CO}_{2}$ climate impacts per flight will not show the same significant decrease as is seen in lifecycle $\mathrm{CO}_{2}$ (Krammer et al., 2013).

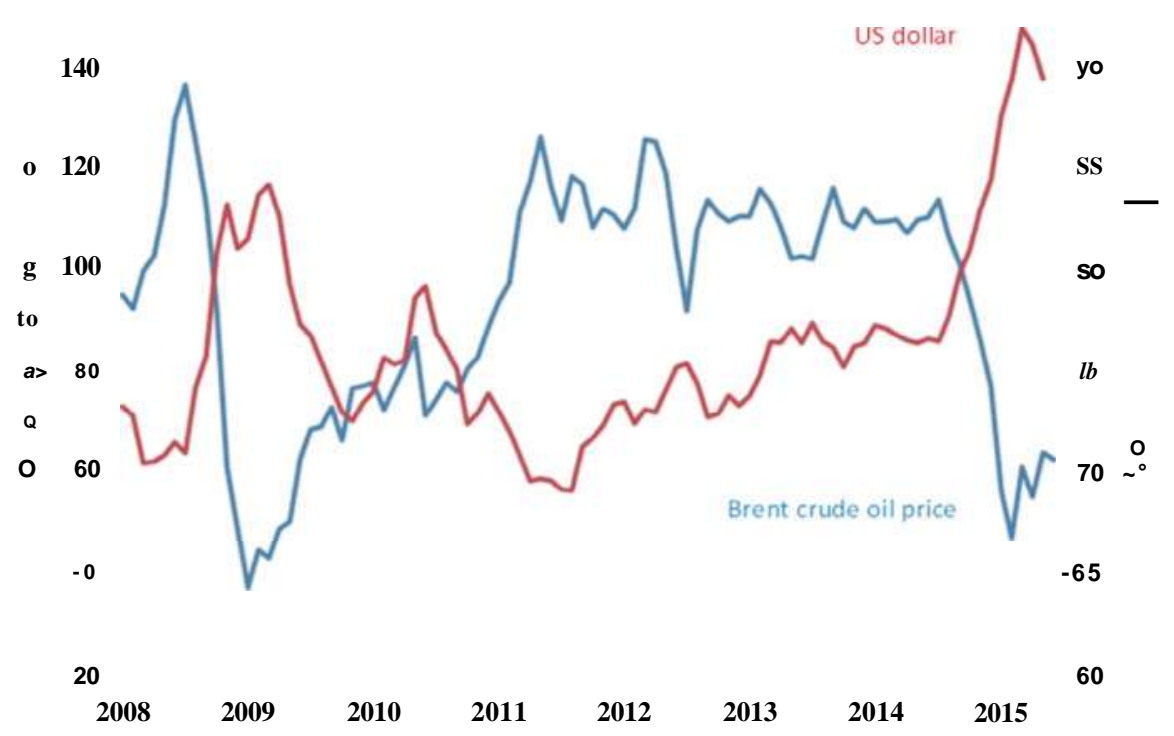

Fig. 2. Relative variation of US dollar and oil price values. 


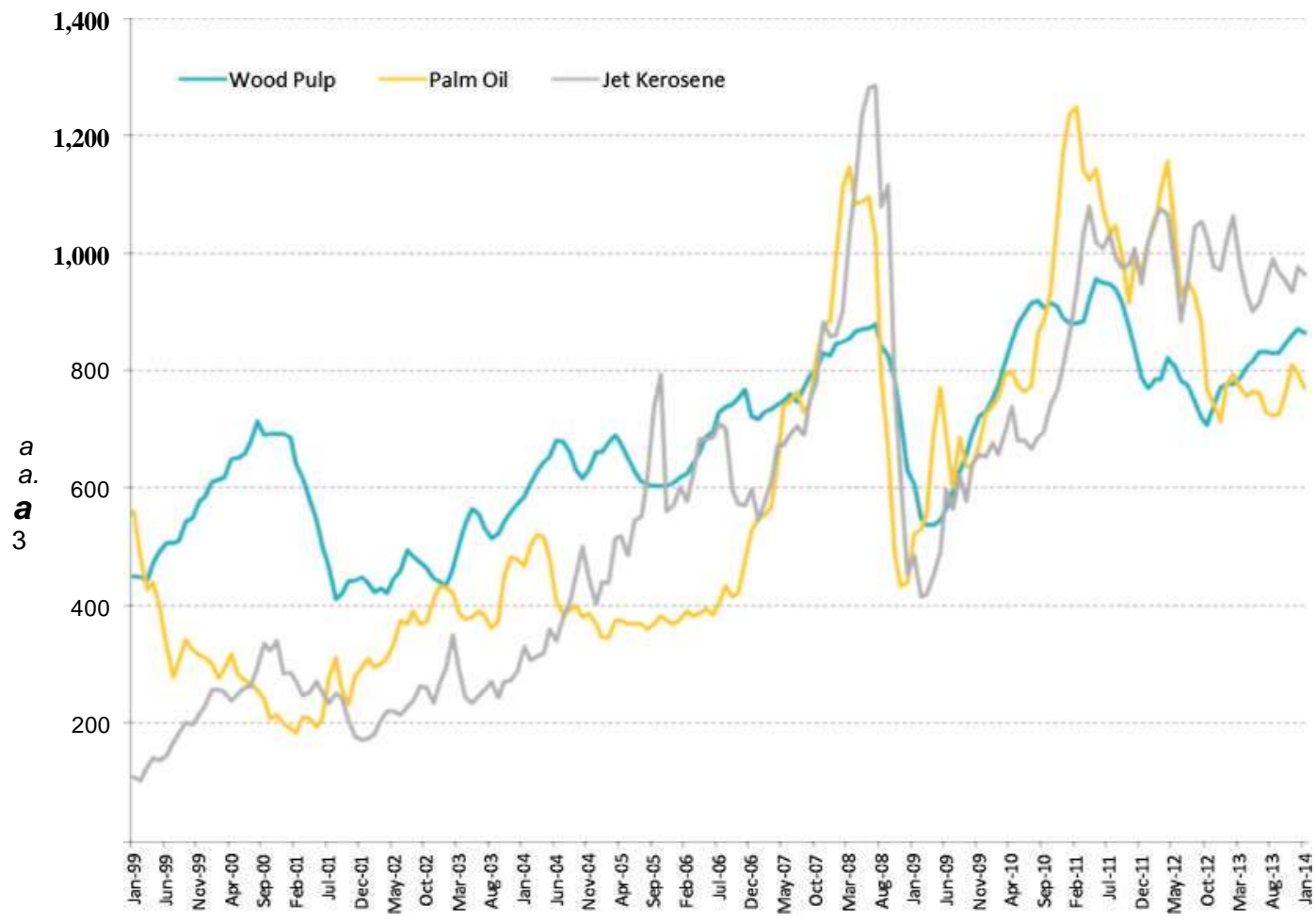

Fig. 3. Cost of Jet kerosene versus selected biofuel raw materials 1999-2014. Source: Index Mundi, (Hind, 2014).

Primary energy from biomass supply (ktoe)

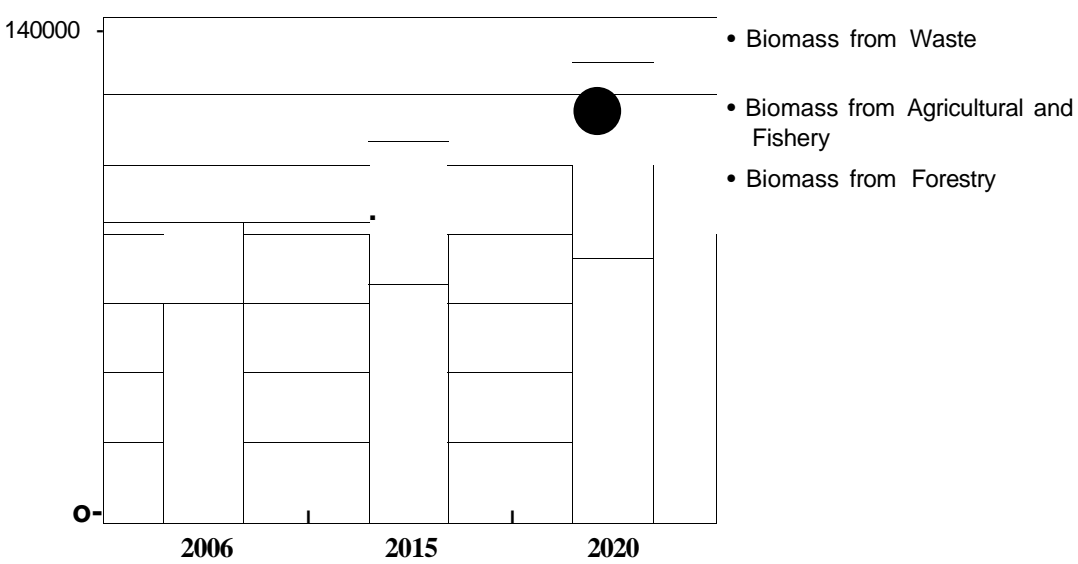

Fig. 4. Expected biomass sources from the NREAPS (Ninni, 2010) in thousands of tonnes of oil equivalent.

Security of supply is more difficult to evaluate (Rye et al., 2010). Additional supplying sources may limit the price increase of the oil as more providers would enter into the market and get up the competition level, but aviation kerosene is taking around $7 \%$ of the oil production and the European part will be close to $2 \%$ of the total oil extraction, very low fraction to have an immediate price repercussion.

The same reasoning is applicable to the additional jobs and wealth created by local production. The total EU renewable energy target for transport increases crop area globally by 5.2 million hectare, equivalent of $0.7 \%$ of the cultivated European surface (Pilzecker, 2011). The economic effect of this action will not be negligible, but it remains to be seen where to find fertile idle land that, by the way, is not a renewable resource. Expected biomass sources for the 2006-2020 period can be seen in Fig. 4 from that reference. 
The present projections of the National Renewable Energy Action Plans (NREAPS), established by the Directive 2009/28/ $\mathrm{EC}$, forecast a $50 \%$ of the agricultural bioenergy in 2020 coming from farming (the so called "energy crops") and the other 50\% being obtained from agricultural waste and residues. This second part would grow much faster as is indicated in Table 2 from the same reference.

As a conclusion, the successful introduction of aviation biofuels will depend on the selection of the right support schemes at European level in order to promote the most efficient type of production in both environmental and economic terms. This does not disregard the possibility of reaching a biofuel production at great scale that makes it more competitive with fossil fuels but it might take a time period out of the 2020-2030 scenarios presently contemplated and there is no indication that support schemes may become unneeded in the foreseeable future.

\section{Incentives policies being applied in the world}

It is widely accepted that the introduction of biofuels cannot be done using current market mechanisms because their high production and distribution cost, at least during the initial stage, limit their competitiveness with fossil fuels. It is not unreasonable to assume that until concerns surrounding cost, sustainability and policy support are addressed, aviation biofuels will not form a significant share of the aviation fuel market (Gegg et al., 2014). Then, all States interested in promoting the use of biofuels are going to use special incentives to gain public acceptance of these new products.

There are several feasible options for incentive policies, varying on the type of economic mechanism applied, subsidies or quotas, and in the phase of the production-consumption cycle where is applied to, farming, recollection, manufacturing, distribution or consumption. Each State or even part of it, like the Federal States of USA and Canada, may select the combination of measures that fits the best to its particular environment and produces less interference with other related activities, like food agriculture, rural development or other energy production.

The key instruments widely adopted to foster production and increase consumption have been mandatory blending targets, tax exemptions and subsidies. In addition, governments have intervened on the production chain by supporting intermediate inputs (feedstock crops), subsidizing value-adding factors (labour, capital, and land) or granting incentives that target end-products. Import tariffs have also played a significant role by protecting national industries from external competition (Sorda et al., 2010).

In the United States (Yacobucci, 2012) there were some legislative actions to launch alternative energy production, like the 2005 Energy Policy Act, the 2007 Energy Independence and Security Act and the 2008 Farm Bill. Biofuels, in this case transportation fuels, produced from plants and other organic materials, are of particular interest. Ethanol and biodiesel, the two most widely used biofuels, received significant federal support in form of tax incentives, loan and grant programs and regulatory programs The Table 3 listed 22 recent Federal programs that provide direct or indirect incentives for biofuels, grouped by administering agency. Some of them are long term, some have a fix deadline and others need Senate or Congress approval for continuity.

As it can be seen, the support schemes are being administrated by six different agencies and departments without any apparent coordination. Many of them have been originated by three major Federal legislative actions previously mentioned, the 2005 and 2007 energy laws and a farm bill in 2008. A great number of them are temporary rules terminating at the end of 2011 or 2012 and will need Congress approval to be extended.

The schemes can be broadly divided in six types:

- A mandate for the use of fixed amounts of renewable fuel in gasoline.

- Tax credits for gasoline suppliers and biofuel producers.

- Financial help for the opening and expansion of supply and production facilities, either new or refurbished.

- Financial help for Research and Development.

- Reduction of import duties for some kinds of biofuels.

- Incentives to manufacturers for production and sale of alternative fuel vehicles

but can be resumed in two groups: mandate for blending and tax measures.

The distribution of incentives goes along the whole biofuel chain, from the agriculture to the vehicle, passing through the production plants, the refineries and the distribution, with selective inclusion of some products (fuel ethanol) in an import duty rebate. All these policies have a cost for the tax payer, diminishing the public treasure revenues. No information has been published on that amount.

Table 2

Projections of the National Renewable Energy Action Plans (NREAPS) on the agricultural bioenergy in 2020 coming from agricultural waste and residues.

$20052030 \quad 2050$ 
Table 3

US Federal programs providing direct or indirect incentives for biofuels (Congressional Research Service).

Administering
agency
Environmental
Protection
Agency (EPA)
Internal Revenue
Service (IRS)

Department of Agriculture (DOA)

Department of
Energy (DOE)

U.S. Customs and
Border Protection
Department of
Transportation
(DOT)

Program

Renewable fuel standard

Volumetric ethanol excise tax credit

Small ethanol producer credit

Biodiesel tax credit

Small agri-biodiesel producer credit

Renewable diesel tax credit

Credit for production of cellulosic biofuel

Special depreciation allowance for cellulosic biofuel plant property Alternative fuelling station credit

Biorefinery assistance

Repowering assistance

Bioenergy program for advanced biofuels

Feedstock flexibility program for producers of biofuels Biomass crop assistance program (BCAP)

Rural Energy for America Program (REAP)

Biomass Research and Development

Biorefinery project grants

Loan guarantees for ethanol and commercial byproducts from various feedstocks

DOE Loan guarantee program

Cellulosic ethanol reserve auction

Import Duty for fuel ethanol

Flexible fuel vehicle production incentive
Description

Mandated use of renewable fuel in gasoline: 4 billion gallons (2006), 36 billion gallons (2022)

Gasoline suppliers who blend ethanol with gasoline are eligible for a tax credit of 0.45 USD per gallon of ethanol

An ethanol producer with less than 60 million gallons per year in production capacity may claim a credit of 0.10 USD per gallon on the first 15 million gallons produced in a year

Producers of biodiesel or diesel/biodiesel blends may claim a tax credit of 1 USD per gallon of biodiesel

An agri-Biodiesel (produced from virgin agricultural products) producer with less than 60 million gallons per year in production capacity may claim a credit of 0.10 USD per gallon on the first 15 million gallons produced in a year Producers of renewable diesel may claim a tax credit of 1 USD per gallon of renewable diesel

Producers of cellulosic biofuel may claim a tax credit of 1.01 USD per gallon, under some specific conditions

Plants producing cellulosic biofuels may take a 50\% depreciation allowance in the first year of operation, subject to certain restrictions

A credit up to 30,000 USD is available for the installation of alternative fuel infrastructure, including E85 (85\% ethanol and 15\% gasoline) pumps

Loan guarantees and grants for the construction and retrofitting of biorefineries to produce advanced biofuels

Grants to biorefineries that use renewable biomass to reduce or eliminate fossil fuel use

Provides payments to producers to support and expand production of advanced biofuels

Authorizes the use of COC (Commodity Credit Corporation) funds to purchase surplus sugar, to be resold as a biomass feedstock to produce bioenergy

Provides financial assistance for biomass crop establishment costs and annual payments for biomass production; also provides payments to assist with costs for biomass collection, harvest, storage, and transportation

Loan guarantees and grants for a wide range of rural energy projects, including biofuels

Grants for biomass research, development and demonstration programs

Funds cooperative R\&D on biomass for fuels, power, chemicals and other products

Several programs of loan guarantees to construct facilities that produce ethanol and other commercial products from cellulosic material, municipal solid waste, and/or sugarcane

Loan guarantees for energy projects that reduce air pollutant and greenhouse gas emissions, including biofuels projects

Authorizes DOE to provide per-gallon payments to cellulosic biofuels producers

All imported ethanol is subject to a $2.5 \%$ ad valorem tariff; it is also subject to a most-favoured-nation added duty of 0.54 USD per gallon

Automakers subject to Corporate Average Fuel Economy (CAFE) standards may accrue credits under that program for the production and sale of alternative fuel vehicles, including ethanol/gasoline flexible fuel vehicles (FFVs)

The second generation biofuels for transport are included in the Renewable Fuel Standard (RFS) law. President Obama supports the preservation of the RFS, as a part of an "all of the above energy strategy", based on a public-private finance scheme. However, there is fear that affordable private capital will not be available to support any major capacity building for advanced biofuels, putting the RFS itself, with its steep annual volumetric increases, in considerable jeopardy. The resulting lack of capacity and rewriting of mandates to support lower levels of capacity building may result in market uncertainty and further reduce investor interest in the sector.

A large variety of biofuel support policies are in place in EU Member States (Wiesenthal et al., 2009), ranging from command and control instruments such as standards and quotas, over economic and fiscal measures, such as tax exemptions, to information diffusion, and addressing different stages of the biofuel chain.

As first generation biofuels are a mature product, the policy focus today lies on facilitating their market entry rather than $R \& D$ support. As the production cost of biofuels is well above those of fossil fuels, incentive policies are needed to create the biofuels market. This is done, as in the United States, by two types of instruments: subsidization or prescription of a 
mandatory production. In the first case a tax reduction scheme brings the price of bio fuel down to the price of the equivalent fossil fuel, reducing the State income. In the second case, fuel providers are obliged to blend a certain percentage or gross amount of biofuel in their product. In this way, fuel providers and the transport users carry the additional cost and a certain reduction of demand is caused. Similar schemes may be applied to other elements, like fiscal support to the sale or utilisation of dedicated vehicles, either in their sale price or in the owner taxes or the circulation conditions e.g. allowing bio fuelled vehicles to circulate by restricted lanes or to have access to the big cities downtown.

Unlike the United States, the EU has tried to get a higher level of coordination in the State aid policies, defining global targets and standardizing legal and economic procedures, but leaving Member States some open space to determine the level of each policy application and the mix of support schemes more adequate to their particular characteristics. In any case, the used tools are very similar to those used in other countries, divided in fiscal measures and blending obligations.

The legal framework for the fiscal measures is the EU Energy Taxation Directive 2003/96/EC that allows exempting all types of biofuels from taxes if:

- The tax exemption or reduction does not exceed the amount of taxation payable on the volume of renewables used;

- Changes in the feedstocks prices are accounted for in order to avoid overcompensation;

- The exemption or reduction authorized may not be applied for a period of more than six consecutive years, renewable.

In April 2014 the European Commission introduced new guidelines on state aid for renewable energy (EU, 2014), including biofuels (EBTP, 2014), with the purpose of providing a framework for designing more efficient public support measures that reflect market conditions. According to the Commission Vice President in charge of competition policy, Joaquin Almunia, Europe should meet its ambitious energy and climate targets at the least possible cost for taxpayers and without undue distortions of competition in the Single Market.

Three months before, on January 23, 2014, the Commission had published a communication titled: A policy framework for climate and energy in the period from 2020 to 2030. In relation to biofuels, the communication confirmed the relevancy of the 2020 targets (10\% of renewable fuels for the transport sector) and acknowledges the achieved progress, with a $4.7 \%$ rate in 2010 compared with a $1.2 \%$ in 2005 . Based in the past experience, the Communication concluded that first generation biofuels have a limited role in decarbonising the transport sector and a range of alternative renewable fuels and a mix of targeted policy measures building on the Transport White Paper are thus needed to address the challenges of the transport sector in a 2030 perspective and beyond. No specific 2030 target was announced.

The April 2014 guidelines on State aid made reference to biofuels for trying to progressively reduce support of first generation biofuels (called food-based biofuels), without causing a sudden disruption on the industry. It considered that investment aid in new and existing capacity for food-based biofuels is not justified, in view of the existing overcapacity in this market, but this aid can be justified for increasing capacity in advanced biofuels or in the conversion of the existing facilities in these ones. Thus investment aid to support food based biofuels is stopped with the entry into force of these guidelines.

Operating aid for first generation biofuels will cease at the end of 2020. This aid can only be granted to the production of plants that started operation before 31 December 2013 until the plant is fully depreciated but in any event no later than 2020.

With respect to biofuels subject to supply or blending obligations, aid can be provided if a Member State can demonstrate that the aid is limited to sustainable biofuels that are too expensive to come on the market with a supply or blending obligation only. The concept of "sustainable biofuel" refers to those fulfilling the sustainability criteria set out in Article 17 of the Directive 2009/28/EC (EU, 2009).

During the second half of 2013 both the European Council and the European Parliament were extensively discussing the possibility of putting a cap on the first generation biofuels utilisation and how to include the ILUC factor in the accounting of environmental impact of biofuels. No agreement was reached, but the issue is expected to appear again after the recent European Elections, with the goal of achieving a final decision at the end of 2015.

With respect to the blending obligations, each country may apply its selected amount, based on percentage of energy or volume, making it indicative or obligatory or minimum level. For example, Estonia, Greece and Lithuania have only indicative blending amounts and Denmark adopted a first-ever obligatory quota in 2011. Those blending levels may be different for biodiesel and bioethanol, and have been slowly increasing during the last years. Table 4 shows the status of blending obligations in the EU and Norway (associated State in bioenergy policies) in the year 2011. Sales of biofuels reached 13.9 million tonnes; a $77 \%$ of biodiesel, $21.5 \%$ of bioethanol and $1.5 \%$ of vegetable oil. As it was indicated before, present mandate is $5.75 \%$ and the final target is $10 \%$ of renewable content in 2020 .

USA and the European States are not the only countries with mandates (Lane, 2013). A total of thirteen American States, including Argentina, Brazil, Canada, Chile, Costa Rica, Ecuador, Jamaica, Mexico, Panama, Paraguay, Peru, Uruguay and the United States itself have different blending obligations, putting more emphasis on ethanol than in biodiesel. Some federal countries, like Canada, use different figures in each one of its States.

In the Asia-Pacific region, other twelve States have implemented this kind of policies, namely Australia, China (in nine provinces only), Fiji, India, Indonesia, Malaysia, New Zealand, The Philippines, South Korea, Taiwan, Thailand and Vietnam. Ten African States, Angola, Ethiopia, Kenya, Malawi, Mozambique, Nigeria, South Africa, Sudan, Zambia and Zimbabwe have ethanol blending obligations, but South Africa who has a biodiesel mandate as well. A total of 62 of the world larger 
Table 4

Blending obligations in the EU, measured in \% of energy (Vecchiet, 2011).

\begin{tabular}{|c|c|c|c|}
\hline Member state & Total \% & Biodiesel \% & Bioethanol \\
\hline Belgium & 4 & - & - \\
\hline Bulgaria & $5^{\mathrm{a}}$ & $4^{\mathrm{a}}$ & $2^{\mathrm{a}}$ \\
\hline Czech Republic & - & $6^{\mathrm{a}}$ & $4.1^{\mathrm{a}}$ \\
\hline Denmark & 3.5 & - & - \\
\hline Germany & 6.25 & $4.4(\min )$ & $2.8(\min )$ \\
\hline Estonia & 5.75 (indicative) & - & - \\
\hline Ireland & $4^{\mathrm{a}}$ & - & - \\
\hline Greece & 5.75 (indicative) & - & - \\
\hline Spain & 7 & $6(\min )$ & $3.9(\min )$ \\
\hline France & $7^{\mathrm{a}}$ & $7^{\mathrm{a}}$ & $7^{\mathrm{a}}$ \\
\hline Italy & 4 & - & - \\
\hline Cyprus & 2.5 & - & - \\
\hline Latvia & $5.75^{\mathrm{a}}$ & - & - \\
\hline Lithuania & 5.75 (indicative) & - & - \\
\hline Luxembourg & - & - & - \\
\hline Hungary & 5.75 & $4.4^{\mathrm{a}}$ & $4.4^{\mathrm{a}}$ \\
\hline Malta & - & - & - \\
\hline Netherlands & $4.25^{\mathrm{a}}$ & 3.5 & 3.5 \\
\hline Austria & 5.75 & $6.3(\min )$ & $3.4(\min )$ \\
\hline Poland & 6.2 & - & - \\
\hline Portugal & 5 & $6.75^{\mathrm{a}}$ & - \\
\hline Romania & 5.75 & $5^{\mathrm{a}}$ & $5^{\mathrm{a}}$ \\
\hline Slovenia & 5.5 & - & - \\
\hline Slovak Republic & 5.75 & $5.2^{\mathrm{a}}(\min )$ & $3.1^{\mathrm{a}}(\min )$ \\
\hline Finland & 6 & - & - \\
\hline Sweden & 5.75 (indicative) & - & - \\
\hline United Kingdom & $4^{\mathrm{a}}$ & - & - \\
\hline Norway (non EU) & $5^{\mathrm{a}}$ & & \\
\hline
\end{tabular}

${ }^{a}$ Indicates $\%$ by volume.

economies, with the notable absences of Japan, Russia and the Arabian Gulf States, are in the list. The highest consumers Brazil, China, EU, and United States are targeting average mixes of 10-15\% in the 2020-2025 period (Lane, 2013).

In the proceedings of the Workshop on March 20, 2012 in Brussels (Bauen et al., 2012) there are some examples of financial aid possibilities to build up second generation biofuels production capacity. There is a general consensus on the need of public financial aid for Research and Development and on the convenience of public-private consortia for the initial phases of the production. The banking sector offers a very uneven perspective. Some public banking institutions, like the European Investment Bank (EIB), are lending considerable sums to renewable energy projects. EIB itself lent 4500 million euros in 2011, although the largest part went to well established sectors, like wind energy.

The private banking is a bit hesitant to finance biofuels because of their financing experiences with the first generation biofuel projects, suffering of current overcapacity and dependency on frequently changing policies, sometimes in different countries around the world, but often within the same State, according to the fluctuations of the economy.

The key success factors that any bioenergy project should bring to the table, when requesting for bank financing are:

- Logistic and location.

- Price risk management.

- Feedstock supply with easy and assured access.

- Assured take-off contracts.

- Convincing capacity utilisation expectations (equal or higher than $75 \%$ ).

- Bring in experience management.

- Comply with sustainability criteria.

In the case of the aviation biofuels, most of those conditions are very far of being confirmed, what makes direct financing by commercial banks very unlikely without the direct participation of the Governments through any of the tools before commented.

\section{Discussion}

Different support schemes have different characteristics, adjusting better or worse to the local market conditions. It is risky to pick up one as the optimum for worldwide application. With the experience gained during the last years in the United States and EU markets, it is possible to reach some initial approach to the virtues of each mechanism (Ziolkowska et al., 2010), by reviewing one by one their main features. 
Indicative/mandatory targets: Indicative targets give more flexibility for taking into account the particular conditions of different countries and for adapting to the changing results of yearly crops. Mandatory option largely determines the target credibility, meaning more efforts by the governments to achieve the targets. This in turn means that the markets have greater certainty for planning and undertaking investments.

Volumetric/percentage targets: Volumetric mandates reduce uncertainty faced by biofuels producers and farmers. Percentage targets addresses the commitment of the sector in meeting the overall greenhouse emissions Kyoto Protocol limits. The effectiveness of either type of mandate is conditional on its interaction with any other policy or technical restriction that is in place and that impact biofuel use. For instance, older road vehicles cannot use higher blends and limit the applicable percentage of biofuel.

Incentives for second generation biofuels/quantitative distribution of mandate by type: The first approach, used by the EU, is more flexible in that the volume of second generation biofuels is related to their competitiveness with respect to other biofuels. The US approach provides more certainty by setting a mandate volume, but this mandate can be waived depending on technology available and this undermines its theoretical advantages.

Supranational/country level strategies: The current decentralized approach of the EU has the advantage of allowing countries to find the most effective means to achieve the targets, which may differ country by country. In the USA, it is the Renewable Identification Number (RIN, a 38 character numeric code that goes with each biofuel package, identifying its vintage, volume and fuel classification) market that allows production and distribution to move to the most cost-effective facilities and regions.

Subsidies/mandates: The subsidy system has been largely implemented in Europe to the first generation biofuels, causing significant revenue losses for the governments. However, tax exemptions have the ability to steer the market by applying different reduction rates to various types of biofuels. With the mandatory obligation to blend, fuel suppliers are obliged to achieve a certain share of biofuels in their total fuel sales. This instrument does not cause any revenue losses for the government since the fuel supplier and final consumers are carrying the financial burden of this measure. The higher prices reduce transport fuel demand compared to tax-exemption scheme. There is currently a hectic controversy on whether a combination of obligation to blend and simultaneous tax relief may be the most effective instrument, as EU maintains. Other researchers suggest that a biofuel mandate is fully equivalent to a combination of fuel taxes and biofuel subsidies that is revenue neutral. According to this approach, the mandate alone would be sufficient and any further subsidies would be income transfers from taxpayers to customers.

With increasing demand and decreasing marginal fuel efficiency improvements, the contribution of aviation to climate change relative to other sectors is projected to increase in the future, but it is difficult to predict how much (Sgouridis et al., 2011). Some analysis opens the incertitude margin for the EU ranging from $10 \%$ to $50 \%$ of all greenhouse gas emissions by 2050 .

According to the IEA (International Energy Agency), biofuels could meet $27 \%$ of the transport fuel demand by 2050 (Vessia et al., 2013), with a key role played by advanced biofuels, that need to be rapidly deployed and scaled up. This task would need great and fast progress in three different areas:

- Ensure a stable supply of sustainable feedstocks.

- Support demand by establishing a specific mandate for advanced biofuels by 2020 and beyond.

- Establish mechanisms to finance first of their kind advanced biorefineries.

In favour of this approach success in Europe there is a stepping up of the incentives for second generation biofuels Research \& Development and Innovation with funds provided by the Seventh Framework Programme (FP7) and Horizon 2020 programs, as the target of reducing greenhouse gas emissions of $80 \%$ by 2050 will require a substantial contribution from transport sector, implying an increase of biofuels to an 8-times bigger amount than today.

One of the initiatives financed by FP7 funds is the Initiative Towards sustainable Kerosene for Aviation (ITAKA, 2016), a collaborative project aimed to produce sustainable renewable aviation fuel end to test its use in existing logistic systems and in normal flight operation in Europe. Led by a consortium of aerospace and fuel companies, with academic collaboration, ITAKA intends to make a contribution to the 2 million tonnes of aviation biofuel target by 2020, included in the Flightpath 2020 program, but delayed due to great logistics difficulties up to year 2030.

A very interesting event, related to ITAKA program, is taking place in Norway since February 2016. The Oslo airport Gardermoen has agreed with Air BP the mixing of 790 ton of biofuel in the general fuelling tanks of the facilities. The fuel has been provided by the Finnish company NESTE Oil, elaborated from Spanish camelina. Three airlines accepted to pay an undisclosed amount of money to be allowed to count that fuel in their ETS balance. It is evident that some kind of economic incentive is in use but no official figures on that detail have been published. The owner of the airport AVINOR has a "green fund" which might have been used for that purpose (ITAKA, 2016).

Negative conditions are also important, starting from the strong controversy about the long term use of first generation biofuels, and the slow deployment of the second generation biofuels production plants and a great un-definition of the type of feedstock and processes to be used. The significance of measures on the supply side (Vecchiet, 2011) may therefore increase as a tool to steer a growing biofuel market into the desired direction, yet an additional cost compared to a leastcost approach. A crop specific feedstock support subsidy like the energy crop scheme may help to direct the crop mix into an environmental and landscape-beneficial pathway. It is important to learn from bad experiences, as the ones reported by 
Kant and $\mathrm{Wu}$ (2011) relative to the collapse of Jatropha as a global biofuel in India, China and Brazil and other developing countries that decided to introduce mandatory blending over increasingly larger parts of the country. But the results are anything but encouraging, with actual yields far below expectations. It appears to be an extreme case of a wellintentioned top down climate mitigation approach, undertaken without adequate preparation and ignoring conflict of interest, and adopted in good faith by other countries, gone awry bringing misery to millions of poorest people across the world.

A new and very interesting point is the standardization of the ILUC evaluation techniques that may allow to establish target in terms of climate change effects, like equivalent $\mathrm{CO}_{2}$ emissions, instead of mandates based on volume, weight or energy. At this moment there is no agreement on how to calculate ILUC effect with good level of accuracy, although there are different studies on the subject (Bailis and Baka, 2010). Some ecologist groups are suggesting that certain types of feedstocks produce biofuels with very low life cycle $\mathrm{CO}_{2}$ savings. This will make undesirable from an environmental point of view although may be considered positive from an economical or supply security approach.

The air transport sector can take a good note of the lessons of other transport modes experience. It has some advantages from the technical point of view, because there is a great homogeneity in the vehicles and engines and in the specification of the used fuel. The selection of a drop-in policy makes very clear the feature of the biofuels to be used by this sector. This puts the so-called "blend wall" (the maximum percentage of blended biofuel that is acceptable by the operators) at 50\%, a quantity much higher than in road traffic. At the same time, the specific features of aviation kerosene do not allow the use of most of the current first generation biofuels and strongly reduce the candidate feedstock numbers to a few types (jatropha, camelina, urban waste, algae and some others) of second or third generation.

The existence of EU Emissions Trading System that gives biofuels a zero emission factor may be taken as an incentive for biofuel use. However, the low present price of carbon allowance makes it not very significant. At the same time, the present air transport fuel distribution and logistics system makes difficult to control, through the existing monitoring, reporting and verification system, the credits that specific airlines should be given (SAFUG, 2010). The likely change of the present regional ETS to a worldwide system, perhaps based on an offsetting mechanism, can be influential in the re-evaluation of this incentive.

One additional problem may be the competition with other transport modes. If road transport has to achieve $10 \%$ of renewable energy by 2020, that may cause a shift of all available sustainable biomass to road transportation biofuels production, in particular if first generation biofuel production is limited or eliminated. The study from Heraghty et al. (2013) found that the establishment of a Sustainable Aviation Fuel industry (HEFA and FT) in Australia is technically feasible, but identified the importance of supportive policy environment, in particular a balanced policy environment that incentives the production of all renewable transport fuels equally.

Policy mechanisms for supporting alternative fuels in aviation should comply with the following principles (Bauen and Maniatis, 2012b):

- Parity with other economic sectors.

- Maintain the competitiveness of this transportation mode.

- Ensure high sustainability standards.

- Temporary support mechanisms.

- Focus on reducing investment risk.

The application of blending obligations is more difficult in the air transport sector than in other activities, due to the international character of aviation. A mandate in some countries may imply fuel price differentiation and deviation of connecting traffic through airports not included in the mandate. Also the airlines themselves may have to pay different amounts for fuel depending on the practical implementation of the mandate (by airports, by regions, by countries, by continents). This rises the convenience of applying provisionally mandates by airlines until the biofuel market is stabilized, the use of tradable certificates, as the RINs in USA is other possibility to be considered.

Tax exemptions or subsidies seem to be easier to apply in the production and distribution phases than to the operator, leaving aside the already commented ETS case. At this moment (March 2016), more than one year after the drop of oil prices, the gap between the price of the fossil kerosene and biokerosene is so dramatic that makes almost unthinkable to cover it with public money. Even in the previous 2014 situation, the most promising feedstocks appears to be more expensive than fossil kerosene. Table 5 (Escobar et al., 2016) shows a comparison of prices used in ITAKA calculations, assuming industrial production levels of advanced biofuels. For reference, 2016 price of kerosene tonne is around $300 €$.

Table 5

Potential future evolution of selected feedstocks biofuel production, compared with fossil kerosene (2014 economic conditions).

\begin{tabular}{|c|c|c|c|c|c|c|c|c|c|c|c|c|c|c|c|}
\hline e/ton & 2016 & 2017 & 2018 & 2019 & 2020 & 2021 & 2022 & 2023 & 2024 & 2025 & 2026 & 2027 & 2028 & 2029 & 2030 \\
\hline Salicomia & - & 1037 & 1034 & 1032 & 1030 & 1027 & 1025 & 1022 & 1020 & 1017 & 1014 & 1012 & 1009 & 1007 & 1004 \\
\hline Camelina & 873 & 871 & 869 & 866 & 864 & 861 & 859 & 856 & 854 & 851 & 848 & 846 & 843 & 841 & 838 \\
\hline Jatropha & - & 1006 & 1004 & 1001 & 99 & 996 & 994 & 991 & 989 & 986 & 984 & 981 & 978 & 976 & 973 \\
\hline Microalgae & - & 1793 & 1775 & 1757 & 1738 & 1720 & 1701 & 1682 & 1663 & 1644 & 1625 & 1605 & 1585 & 1565 & 1545 \\
\hline Kerosene & 660 & 674 & 686 & 700 & 713 & 726 & 740 & 753 & 766 & 779 & 793 & 806 & 819 & 832 & 845 \\
\hline
\end{tabular}


However, tax exemptions or financial grants for $R \& D$ and start-ups plants seems an acceptable option during the first years of second generation biofuels initial high scale production in a foreseeable future in which oil prices will have got back to the increasing trend. As civil aviation works on a set of internationally agreed rules, a general agreement on the treatment of the different categories of biofuel (first, second and third generation) would be needed in order to create a levelled playing field for the international airlines.

\section{Conclusions}

Within the existing economic conditions it is not possible to achieve a Carbon Neutral Growth in the civil aviation sector without introducing alternative fuels with a smaller carbon footprint or reducing drastically the activity of the sector. While the use of low carbon fuels like liquid hydrogen might be feasible in the long term, only drop-in biofuels have been demonstrated for short term applications, but their present economic features make necessary some incentive measures, at least during the introductory phase.

As the drop-in biofuels for aviation has only been produced in a experimental scale, the potential cost of producing them in industrial conditions cannot be calculated now with a great level of accuracy, but it seems to be higher than fossil kerosene price in most forecast. It implies the need of some market based incentive to encourage the use of these products and allow the economic conditions to be produced at large scale.

There are different experiences in many countries of incentive schemes applied in other sectors, mainly in the automotive market, but none of them have been tested in the international field under common rules, something essential in the civil aviation field. This requires agreements on type of feedstock, level of blending and some kind of targets, before selecting the applicable economic tools. It is essential to build up a widely accepted Monitoring, Verification and Reporting (MRV) procedures and a clear LCA assessment calculation for both fossil kerosene and alternate biofuels in order to quantify the achievable $\mathrm{C}_{2}$ savings, avoiding double counting, and to be used as basis of a worldwide market based mechanism.

The most promising approach, after looking to other transportation sectors, seems to be the subsidies through advanced tax management or offset mechanism, combined with a minimum level of mandatory blending, but other combinations are workable if a worldwide consensus is achieved a condition unavoidable in the civil aviation universe.

\section{Acknowledgement}

The research work presented in this paper has received funding from the European Union's Seventh Programme for research, technological development and demonstration under Grant Agreement No [308207], ITAKA

\section{References}

Agusdinata, D.B., Zhao, F., Ileleji, K., DeLaurentis, D., 2011. Life cycle assessment of potential biojet fuel production in the United States. Environ. Sci. Technol. $45(21), 9133-9143$.

Alonso, Gustavo, Benito, Arturo, Lonza, Laura, Kousoulidou, Marina, 2014. Investigations on the distribution of air transport traffic and $\mathrm{C}_{2}$ emissions within the European Union. J. Air Transport Manage. 36, 85-93.

American Society for Testing and Materials (ASTM), 2011. Standard Specification for Aviation Turbine Fuel containing Synthesized Hydrocarbons. ASTM D7566, July 2011.

ATAG, 2010. The Right Flightpath to Reduce Aviation Emissions. ATAG, Geneva.

ATAG, 2011a. Beginner's Guide to Aviation Biofuels, second ed., September 2011.

ATAG, 2011b. Powering the Future of Flight. The Six Easy Steps to Growing a Viable Aviation Biofuels Industry (No. Web Version). Air Transport Action Group (ATAG), Geneva.

Azzam, H., Bonnefoy, P., Hansman, RJ., 2010. Investigation of fuel efficiency of the US Air Transportation network structure. In: 10th AIAA ATIO Conference, Fort Worth.

Bailis, R.E., Baka.J.E., 2010. Greenhouse gas emissions and land use change from Jatropha curcas-based jet fuel in Brazil. Environ. Sci. Technol. 44 (22), $8684-$ 8691.

Bauen, Ausilio, Maniatis, Kyriakos, 2012a. Biofuels FlightPath Workshop on Upstream R\&D and Innovation for Biofuels in Aviation, Milan, 18 June 2012.

Bauen, Ausilio, Maniatis, Kyriakos, 2012b. Biofuels FlightPath Workshop on Incentives for Biofuels in Aviation, Brussels, 20 June 2012.

Bauen, Ausilio, van den Heuvel, Eric, Maniatis, Kyriakos, 2012. Biofuels Flightpath Workshop on Financial Mechanisms for Advanced Biofuel Flagship Plants. Brussels, 20 March 2012.

Benito, Arturo, 2007. Climate change impact as a constraint to the air transport growth: the European case. In: World Conference of Transport Research Society, Berkeley.

Benito, Arturo, 2012. Sustainable air transport: governance and regulatory framework. In: Seminar on Strategies for sustainable Development of Air Transport in Brazil. ANAC.

Birdlife European Division, European Environmental Bureau, FERN, Friends of the Earth Europe, Oxfam International, \& Transport and Environment, 2009. Biofuels. Handle with care. An Analysis of EU Biofuel Policy with Recommendations for Action, Brussels

CE Delft, 2015. Assessing Progress Towards Implantation of the ILUC Directive. 4.H38.1. Delft.

De Gorter, H., Just, D.R., 2010. The social costs and benefits of biofuels: the intersection of environmental, energy and agricultural policy. Appl. Econ. Perspect. Policy 32 (1), 4-32.

Demirbas, A., 2009. Political, economic and environmental impacts of biofuels: a review. Appl. Energy 86 (1), S108-S117.

Dessens, O., Kohler, M., Rogers, H., Jones, R., Pyle, J., 2014. Aviation and climate change. Transport Policy 34.

Dray, L.M., Schafer, A, Ben-Akiva, M.E., 2012. Technology limits for reducing EU transport sector $\mathrm{C}_{2}$ emissions. Environ. Sci. Technol. 46 (9), $4734-4741$.

Escobar, A., Martin, R, Benito, A., 2016. Analisis de la introduction a gran escala de biocombustible para la aviacion en la UE. ETSIAE, Universidad Politecnica de Madrid.

EUROCONTROL, 2015. 〈www.eurocontrol.int/single-european-sky>.

European Biofuels Technology Platform, 2014. Biofuels Policy and Legislation, <http://bofuelstp.eu/legislation.html>.

European Environment Agency, 2013. EU bioenergy potential from a resource-efficiency perspective. EEA Report No 6/2013. 
European Union, 2001a. Directive 2001/77/EC on the Promotion of Electricity Produced from Renewable Energy Sources in the Internal Electricity Market (27 September 2001). OJEU, 27.10.2001.

European Union, 2001b. White Paper European transport Policy for 2010: Time to Decide. COM (2001) 370 Final, Brussels 12 September 2001.

European Union, 2003. Directive 2003/30/EC on the Promotion of the Use of Biofuels or Other Renewable Fuels for Transport (8 May 2003). OJEU, 17.5.2003.

European Union, 2009. Directive 2009/28/EC on the Promotion of the Use of Energy from Renewable Sources and Amending and Subsequently Repealing Directives 2001/77/EC and 2003/30/EC (23 April 2009). OJEU, 5.6.2009.

European Union, 2015. Directive 2015/1513/EC Amending Directive 98/70/EC Relating to the Quality of Petrol and Diesel Fuels and Amending Directive 2009/28/EC on the Promotion of the Use of Energy from Renewable Fuels. Brussels, 19 September 2015.

European Union Commission, 2008. Directive 2008/101/EC of 19 November 2008 Amending Directive 2003/87/EC so as to Include Aviation Activities in the Scheme for Greenhouse Gas Emission Allowance Trading within the Community.

European Union Commission, 2011. Launch of the European Advanced Biofuels Flightpath. Brussels, June 2011.

European Union Commission, 2014. Guidelines on State aid for Environmental Protection and Energy 2014-2020. Brussels, 9 April 2014.

Federal Aviation Agency, 2015. <www.faa.gov/nextgen>.

Forsyth, P., 2011. Environmental and financial sustainability of air transport: are they incompatible? J. Air Transport Manage. 17.

Gegg, P., Budd, L., Ison, S., 2014. The market development of aviation biofuel: drivers and constraints. J. Air Transport Manage. 39.

Gnansounou, Edgar, Panichelli, Luis, Dauriat, Arnaud, Villegas, Juan David, 2008. Accounting for indirect land-use changes in GHG balances of biofuels. Working Paper Ref. 437.101. Ecole Polytechnique Federal de Lausanne.

Halog, A., Manik, Y., 2011. Advancing integrated systems modelling framework for life cycle sustainability assessment. Sustainability 3 (12), $469-499$.

Heraghty, B., Elverton, J., Valastro, J., van Ewijk, F., Burgher, L., Branighan, J., 2013. Feasibility Study of Australian Feedstock and Production Capacity to Produce Sustainable Aviation Fuel. Qantas Airways Ltd., Mascot, Australia.

Hind, Peter, 2014. The Commercial Use of Biofuels in Aviation. Regional International.

IATA, 2009. The IATA Technology Roadmap Report. IATA, Montreal.

IATA, 2012. A Global Approach to Reducing Aviation Emissions. First Stop: Carbon-neutral Growth from 2020. IATA, Montreal.

IATA, 2013. II. Resolution on the implementation of the aviation "CNG2020" strategy. Retrieved 22-06-2013, 2013.

IATA, 2015. Economic Performance of the Airline Industry, Geneva.

International Air Transport Association IATA, 2001. Flight Path to Environmental Excellence, Montreal.

International Civil Aviation Organization (ICAO) (2004): Operational opportunities to minimize fuel use and reduce emissions. Circular 303, Montreal.

International Civil Aviation Organization (ICAO), 2013a. CAEP/9 agreed certification requirement for the aeroplane $\mathrm{C}_{2}$ emissions standard. Circular 337 , Montreal.

International Civil Aviation Organization (ICAO), 2013b. Consolidated statement of continuing ICAO policies and practices related to environmental protection. A38-18 General Assembly, October 2013.

International Panel on Climate Change (IPCC), 1999. Aviation and the Global Atmosphere. Cambridge University Press.

ITAKA, 2016. 〈www.itaka-project.eu>.

Jiang, Helen, 2013. Key Findings in Aircraft Economic Life. Boeing, Seattle.

Kant, P., Wu, S., 2011. The extraordinary collapse of Jatropha as a global biofuel. Environ. Sci. Technol. 45 (17), 7114-7115.

Kar, R., Bonnefoy, P.A., Hansman, R.J., 2010. Dynamics of Implementation of Mitigating Measures to Reduce $\mathrm{CO}_{2}$ Emissions from Commercial Aviation (No. ICAT-2010-01). Massachusetts Institute of Technology Cambridge, MA, Cambridge, MA.

Kivits, R., Charles, M.B., Ryan, N., 2010. A post-carbon aviation future: airports and the transition to a cleaner aviation sector. Futures 42 (3), 199-211.

Krammer, P., Dray, L., Kohler, M.O., 2013. Climate-neutrality versus carbon-neutrality for aviation biofuel policy. Transport. Res. Part D: Transport Environ. 23, 64-72.

Lane, Jim, 2013. Biofuels mandates around the world. Biofuels Digest, December 31, 2013. <http://www.biofuelsdigest.com>.

Marsh, G., 2008. Biofuels: aviation alternative? Renew. Energy Focus 9 (4), 48-51.

Mitchell, Donald, 2008. A note on rising food prices. World Bank Policy Research Working Paper No. 4682, Washington DC.

Ninni, Augusto, 2010. Policies to support biofuels in Europe: the changing landscape of instruments. AgBioForum 13 (2), $131-141$.

Nygren, E., Aleklett, K., Hook, M., 2009. Aviation fuel and future oil production scenarios. Energy Policy 37 (10), $4003-4010$.

Peeters, P., 2013. Trends in technology and fuel efficiencies and consequences for stringency setting. ICAO CAEP WG3 Information Paper, Madrid.

Pilzecker, Andreas, 2011. Future of biofuels: An agricultural policy perspective. European Biodiesel Board General Assembly, Brussels, 17 November 2011.

Rye, L., Blakey, S., Wilson, C, 2010. Sustainability of supply or the planet: a review of potential drop-in alternative aviation fuels. Energy Environ. Sci. 3 (1), 17-27.

Schafer, A., Waitz, I., 2014. Air transportation and the environment. Transport Policy 34.

Schafer, A., Heywood, J.B., Jacoby, h.D., Waitz, LA., 2009. Transportation in a Climate-constrained World. MIT Press, Cambridge, MA.

Sgouridis, Sgouris, Bonnefoy, Philippe A., Hansman, R John, 2011. Air transportation in a carbon constrained world: long-term dynamics of policies and strategies for mitigating the carbon footprint of commercial aviation. Transport. Res. Part A 45,1077-1091.

Simone, N., Stettler, M., Barrett, S., 2013. Rapid estimation of global civil aviation emissions with uncertainty quantification. Transport. Res. Part D: Transport Environ. 25, 33-41.

Sims, R.E.H., Mabee, W., Saddler, J.N., Taylor, M., 2010. An overview of second generation biofuel technologies. Bioresour. Technol. 101 (6), 1570-1580.

Sims, R., Mercado, P., Krewitt, W., Bhuyan, G., Flynn, D., Holttinen, H., et al, 2011. Integration of renewable energy into present and future energy systems. In: Edenhofer, 0., Pichs-Madruga, R., Sokona, Y., Seyboth, K., Matschoss, P., Kadner, S., Zwickel, T. (Eds.), IPCC Special Report on Renewable Energy Sources and Climate Change Mitigation. Cambridge University Press.

Singh, J., Gu, S., 2010. Commercialization potential of microalgae for biofuels production. Renew. Sustain. Energy Rev. 14 (9), $2596-2610$.

Sorda, G., Banse, M., Kemfert, C, 2010. An overview of biofuel policies across the world. Energy Policy 38 (11), 6977-6988.

Stephens, E., Ross, I.L., King, Z., Mussgnug, J.H., Kruse, 0., Posten, C, et al, 2010. An economic and technical evaluation of microalgal biofuels. Nat. Biotechnol. $28(2), 126-128$.

Stratton, R.W., Wong, H.M., Hileman, J.I., 2010. Life cycle greenhouse gas emissions from alternative jet fuels. PARTNER Project 28 Report, June 2010.

Sustainable Aviation Fuel Users Group (SAFUG), 2010. Governments' Unique Role in Sustainable Aviation Biofuel, August 2010.

Vecchiet, Alessia, 2011. European biofuels blending obligation. Esse community, August 14, 2011. <http://www.essecommunity.eu >

Vera-Morales, M., Schafer, A., 2009. Fuel-Cycle Assessment of Alternative Aviation Fuels. Manchester Metropolitan University, Manchester.

Vessia, Oyvind, Riis Nielsen, Kare, Grassi Giuliano, Urbancic, Nusa, 2013. The future of biofuels as alternative fuel for the transport sector. In: Workshop of the European Parliament Intergroup, Brussels, 16 October 2013.

Vorster, S., Ungerer, M., Volschenk, J., 2012. 2050 Scenarios for long-haul tourism in the evolving global climate change regime. Sustainability 5 (1), 1-51.

Wiesenthal, Tobias, Leduc, Guillaume, Christidis, Panayotis, Schade, Burkhard, Pelkmans, Luc, Govaerts, Leen, Georgopoulos, Panagiotis, 2009. Biofuel support policies in Europe: lessons learnt for the long way ahead. Renew. Sustain. Energy Rev. Part 13, 789-800.

Yacobucci, Brent D., 2012. Biofuels incentives: a summary of federal programs. Congressional Research Service R40110, Washington 11 January 2012.

Ziolkowska, Jadwiga, Meyers, William H., Meyer, Seth, Binfield, Julian, 2010. Targets and mandates: lessons learned from EU and US biofuels policy mechanisms. AgBioForum 13 (4), 398-412. 